\title{
First description of the female of Cbrysilla volupe (Karsch, 1879) (Araneae: Salticidae: Chrysillini) from India, with notes on the species' distribution and life history
}

\section{Первоописание самки Chrysilla volupe (Karsch, 1879) (Araneae: Salticidae: Chrysillini) из Индии, с заметками по распространению и биологии вида}

\author{
John T.D. Caleb ${ }^{1}$, Rajesh V. Sanap ${ }^{2}$, Kaushal G. Patel ${ }^{3}$, \\ Puthoor Pattammal Sudhin ${ }^{4}$, Karunnappilli S. Nafin ${ }^{4}$, \\ Ambalaparambil Vasu Sudhikumar ${ }^{4}$ \\ Ажкон Т.А. Калеб ${ }^{1}$, Раджеш В. Санап ${ }^{2}$, Каушал Г. Пател', \\ Патур Паттамал Судхин \\ Амбалапарамбил Васу Судхикумар ${ }^{4}$
}

\footnotetext{
${ }^{1}$ Zoological Survey of India, Prani Vigyan Bhavan, M-Block, New Alipore, Kolkata - 700 053, West Bengal, India; email: caleb87woodgate@gmail.com.

${ }^{2}$ National Centre for Biological Sciences, Tata Institute of Fundamental Research, Bengaluru - 560 065, Karnataka, India.

${ }^{3}$ 07, Shiv Shakti Co-operative Housing Society, Deshara-Bhatha Road, Bilimora - 395 321, Gujarat, India.

${ }^{4}$ Centre for Animal Taxonomy and Ecology, Department of Zoology, Christ College, Irinjalakuda - 680 125, Kerala, India.
}

KEY WORDS: Africa, individual development, jumping spider, taxonomy, new combination.

КЛЮЧЕВЫЕ СЛОВА: Африка, индивидуальное развитие, паук-скакунчик, таксономия, новая комбинация.

ABSTRACT. Chrysilla volupe (Karsch, 1879) is redescribed based on fresh materials collected from India. The female is described for the first time. Observations on the initial developmental stages of the eggs and the first instar are documented. A map showing the refined distributional range of $C$. volupe is provided. A new combination is proposed for the African species, Chrysilla guineensis (Wesołowska et Wiśniewski, 2013) comb.n. (ex. Phintella), thereby confirming the occurrence of the genus in the Afrotropical Region.

How to cite this article: Caleb J.T.D., Sanap R.V., Patel K.G., Sudhin P.P., Nafin K.S., Sudhikumar A.V. 2018. First description of the female of Chrysilla volupe (Karsch, 1879) (Araneae: Salticidae: Chrysillini) from India, with notes on the species' distribution and life history // Arthropoda Selecta. Vol.27. No.2. P.143153. doi: 10.15298/arthsel. 27.2.06

РЕЗЮМЕ. Вид Chrysilla volupe (Karsch, 1879) переописан по свежему материалу из Индии. Самка описана впервые. Приводится карта уточненного распространения C. volupe, а также наблюдения над начальными стадиями развития яиц и первым возрастом личинок. Предложена новая комбинация, Chrysilla guineensis (Wesołowska et Wiśniewski, 2013) comb.n. (ex. Phintella), тем самым подтверждая нахождение рода в Афротропической области.

\section{Introduction}

The jumping spider genus Chrysilla was erected by Thorell in 1887, with C. lauta Thorell, 1887 as its generotype. The genus currently comprises of ten described species, of which only C. acerosa Wang et Zhang, 2012 and C. jesudasi Caleb et Mathai, 2014 are known from both sexes [WSC, 2018]. Three species C. acerosa Wang et Zhang, 2012, C. jesudasi Caleb et Mathai, 2014 and C. volupe (Karsch, 1879) - have been recorded/described from India to date [Caleb, Mathai, 2014; Caleb, 2016; WSC, 2018].

C. volupe was originally described as Attus volupe from an unknown locality in Sri Lanka [Karsch, 1879]. A century later, the species was redescribed and placed in Phintella based on the re-examination of the holotype, and its range was extended to the mainland of the Indian subcontinent [Żabka, 1988; Caleb, Mathai, 2014]. Later it was transferred to the genus Chrysilla [Caleb, 2016]. However, the species has remained known from the males only for about 139 years, since its original description. In the present paper, we have provided the first description of the female of $C$. volupe and a detailed redescription of its male based on fresh material collected from India. Furthermore, initial developmental stages of the eggs and the first instar 
of $C$. volupe have been observed for the first time. A new combination is proposed for Chrysilla guineensis (Wesołowska et Wiśniewski, 2013) comb.n., (ex Phintella).

\section{Material and methods}

Specimens were hand collected, and live specimens were photographed by means of a Canon DSLR 60D with $60 \mathrm{~mm}$ macro lens and Speedlite 430 EX II external flash and a Canon EOS 5D Mark-III with Canon MP-E 65mm 1-5x macro lens and Canon MT-24EX Macro Twin Lite Flash. The specimens were preserved in $70 \%$ ethanol. Microscopic examination was made under a Leica S8APO stereoscopic microscope. Photographs of diagnostic structures were obtained by means of a Leica MC120 HD camera attached to a stereoscopic microscope with the LAS core software package. Descriptions are based on fresh specimens. Leg measurements are given as follows: total length (femur, patella, tibia, metatarsus, tarsus). All measurements are in millimeters. Voucher specimens are deposited in the research collections of the National Centre for Biological Sciences (NCBS), Bengaluru, Karnataka and at the Centre for Animal Taxonomy and Ecology, Department of Zoology, Christ College, Irinjalakuda, Kerala (CATE).

In order to obtain eggs and then to observe egg and postembryonic development, gravid females were housed in clear round plastic containers $(9 \mathrm{~cm}$ high and $6 \mathrm{~cm}$ in diameter). Wet cotton was placed in the containers to maintain moisture and their temperature was maintained at +25 to $+27^{\circ} \mathrm{C}$. The light regime was 12L:12D.

Abbreviations used in the text and figures: AER anterior eye row width; ALE - anterior lateral eye, AME - anterior median eye, EFL — eye field length; PER - posterior eye row width; PLE - posterior lateral eye, PME - posterior median eye, RTA retrolateral tibial apophysis. AS - Ambalaparambil Vasu Sudhikumar, JC - John T.D. Caleb, KP Kaushal G. Patel, KN - Karunnappilli S. Nafin, PS Puthoor Pattammal Sudhin, RS - Rajesh V. Sanap.

\section{Taxonomy}

\section{Chrysilla Thorell, 1887 \\ Type species: C. lauta Thorell, 1887 \\ Chrysilla volupe (Karsch, 1879) Figs 1-37, Map.}

Attus volupe Karsch, 1879d: 552 (Description of male).

Phintella volupe Zabka, 1988: 465, figs. 122-125 (Description and transfer of male from Attus to Phintella); Caleb, Mathai, 2014b: 64, figs. 15-23 (Description of male).

Siler semiglaucus Prószyński, 1985: 73, figs 16-17 (Misidentified, female only; Prószyński [2016] raises doubts on the conspecificity of the illustrated female).

Chrysilla volupe Caleb, 2016b: 271 (Transfer from Phintella).

MATERIAL EXAMINED. INDIA: $1 \sigma^{7}$ (NCBS-AR048), Bengaluru, Karnataka, NCBS campus $\left(13^{\circ} 04^{\prime} 15.585^{\prime \prime} \mathrm{N}, 77^{\circ} 34^{\prime} 50\right.$. 113"E), $936 \mathrm{~m}$ a.s.1., 18.05.2015, R.V. Sanap \& J. Caleb; 1 q
(NCBS-AU141), same locality $\left(13^{\circ} 04^{\prime} 21.4098^{\prime \prime} \mathrm{N}, 77^{\circ} 34^{\prime} 44\right.$. 3994"E), 933 m a.s.1., 3.06.2016, R.V. Sanap; $1 \sigma^{7}$ (NCBS-AC756), 3 우 (NCBS-AC757-759), Mumbai, Maharashtra, Aarey milk colony $\left(19^{\circ} 08^{\prime} 32.0^{\prime \prime} \mathrm{N}, 72^{\circ} 52^{\prime} 03.3^{\prime \prime} \mathrm{E}\right), 37 \mathrm{~m}$ a.s.1., 5.07.2017, R.V. Sanap \& Imran Udat; $1 \sigma^{7}$ (NCBS-AC760), Gujarat, Pariyej Lake, nr. a bird watch tower $\left(22^{\circ} 32^{\prime} 58.0158^{\prime \prime} \mathrm{N}, 72^{\circ} 37^{\prime} 23.952^{\prime \prime} \mathrm{E}\right), 16 \mathrm{~m}$ a.s.1., 16.06.2017, K.G. Patel; $12 \sigma^{\top} \sigma^{\top}, 5$ Oᄋ (CATE, 8412A), Kerala, Wayanad Wildlife Sanctuary, Bathery range $\left(11^{\circ} 42^{\prime} 09.8^{\prime \prime} \mathrm{N}\right.$, $76^{\circ} 20^{\prime} 39.6^{\prime \prime}$ E). $868 \mathrm{~m}$ a.s.1., 12.06.2015, P.P. Sudhin \& K.S. Nafin; $9 \mathrm{O}^{\top} \mathrm{O}^{\top}, 4$ 우 $($ CATE $8412 \mathrm{~B})$, same range $\left(11^{\circ} 42^{\prime} 01.7^{\prime \prime} \mathrm{N}, 76^{\circ}\right.$ $\left.20^{\prime} 28.1^{\prime \prime E}\right), 866 \mathrm{~m}$ a.s.1., 12.06.2015, P.P. Sudhin \& K.S. Nafin.

DIAGNOSIS. Based on somatic morphology and palpal structure, C. volupe is closely related to C. lauta Thorell, 1887, from which it can be readily distinguished by the following characters: dorsum with a distinct reddish orange pattern (Figs 1, 3, 5, 7, 9) [Caleb, 2016; Żabka, 1988: fig. 125]; proximal protrusion of palpal tegulum sac-like (Figs 18, 20) (more elongated and ' $\mathrm{U}$ '-shaped in C. lauta). C. volupe is also similar to $C$. guineensis, but can be distinguished from it by the following characters: distal tip of palpal tegulum wide (narrowing distally in C. guineensis); anterior half of the copulatory ducts parallel (sub-parallel in C. guineensis); copulatory openings directed laterally (arrowed in Figs 23, 25) (directed anteriorly in C. guineensis) (cf. Figs 22-25 with figs 8, 9 in Wesołowska \& Wiśniewski [2013]).

DESCRIPTION. Male (NCBS-AR048). Total length: 5.44; carapace: 2.14 long, 1.76 wide; abdomen: 3.30 long, 1.30 wide. Carapace covered with reddish orange scales; a pair of broad bluish iridescent transverse stripes present, one behind the anterior eye row and the other between PLEs; a broad quadrangular patch present on the posterior slope (Fig. 11). Anterior eyes surrounded with reddish-orange orbital setae in the upper half and white orbital setae in the lower half; clypeus covered by bluish iridescent scales which diverge laterally, one branching below the lateral eyes almost reaching the posterior patch, the other runs along outer edge of the carapace (Fig. 1). Eye measurements: AME 0.46, ALE 0.27, PME 0.09, PLE 0.26, AER 1.61, PER 1.73, EFL 1.13; AME-AME 0.02, AMEALE 0.04, ALE-PME 0.38, PME-PME 1.45, PMEPLE 0.21, PLE-PLE 1.38. Clypeus height 0.15. Sternum oval, brownish covered with iridescent scales. Chelicerae unidentate, reddish brown (Fig. 15); labium and maxillae brownish. Leg I robust, black; legs II-III yellow; tarsi II-IV white; leg IV with dark brown femur and blackish annulation at joints of each segment, tarsus with blackish proximal half; all legs covered with iridescent scales reflecting metallic shades of golden and purplish tinge (Figs. 1, 3, 7, 9, 11). Leg measurements: I $6.20(1.97,1.05,1.46,1.11,0.61)$; II 4.39 $(1.38,0.72,0.98,0.83,0.48)$; III 4.36 (1.35, 0.59, $0.86,1.01,0.55)$; IV $5.82(1.70,0.66,1.28,1.61,0.57)$. Leg formula: 1423. Abdomen elongate and narrow; covered with fine iridescent hairs; reddish orange scales present mid-dorsally, forming a M-shaped patch resting on a broad transverse patch below. Spinnerets blackish (Figs. 3, 9). Palpal femur, patella, tibia and the proximal half of cymbium black, dorsally covered with 


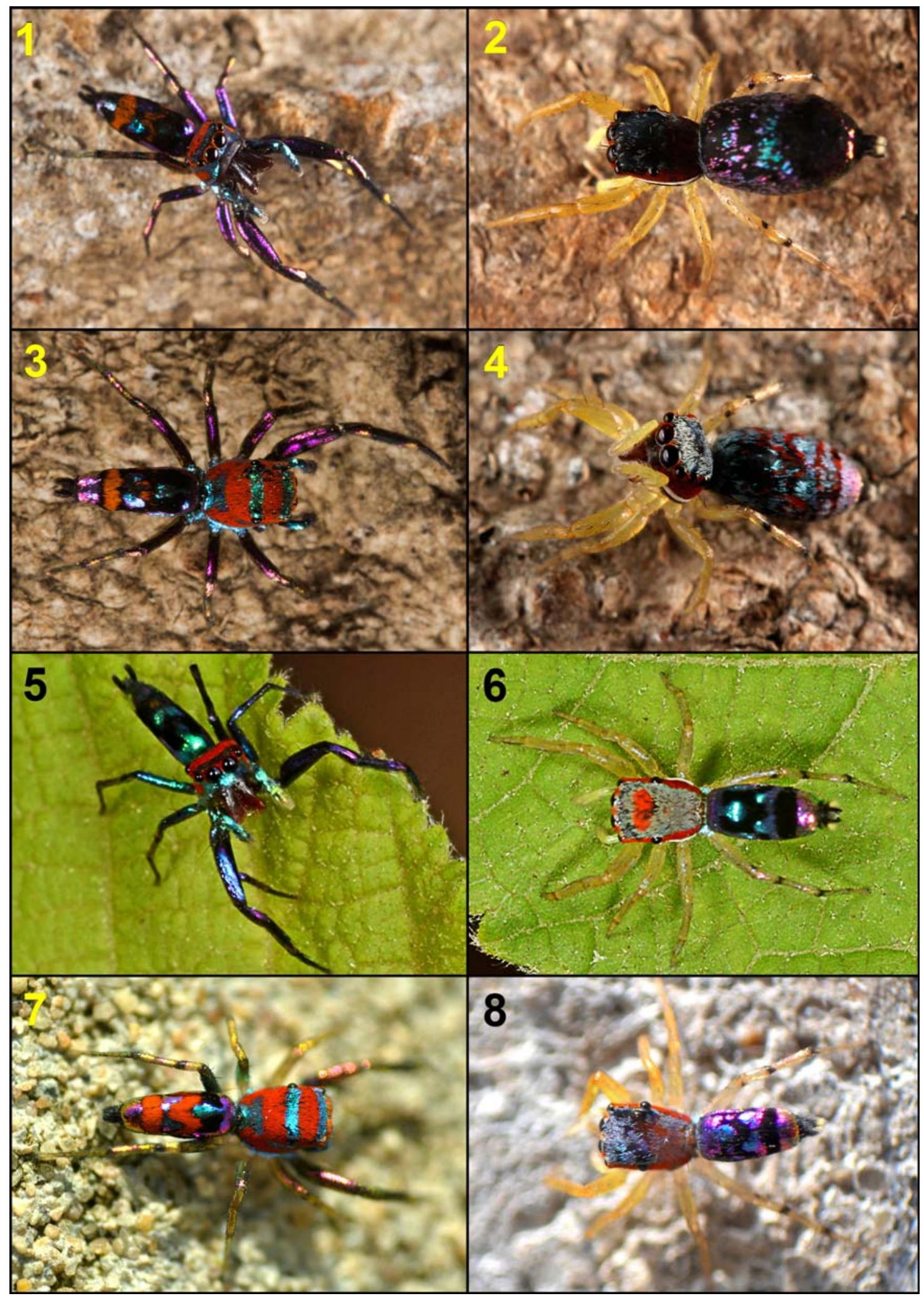

Figs 1-8. General appearance of male $(1,3,5,7)$ and female $(2,4,6,8)$ of Chrysilla volupe (Karsch, 1879): 1-4 — specimens from Aarey Milk Colony, Mumbai; 5-6 - specimens from Nagla, District Thane; 7-8 - specimens from Thirumullaivoyal, Chennai. Photo credits: 1-4 - Rajesh V. Sanap; 5-6 - Yuwraj Gurjar; 7-8 - John Caleb.

Рис. 1-8. Общий вид самца $(1,3,5,7)$ и самки $(2,4,6,8)$ Chrysilla volupe (Karsch, 1879): 1-4 - экземпляры из молочной колонии Арей, Мумбай; 5-6 - экземпляры из Нагла, район Фане; 7-8 - экземпляры из Тирумуллаивоял, Хеннай. Фотографии: 1-4 - Раджеш В. Санап; 5-6 - Юврадж Гурджар; 7-8 - Джон Калеб. 


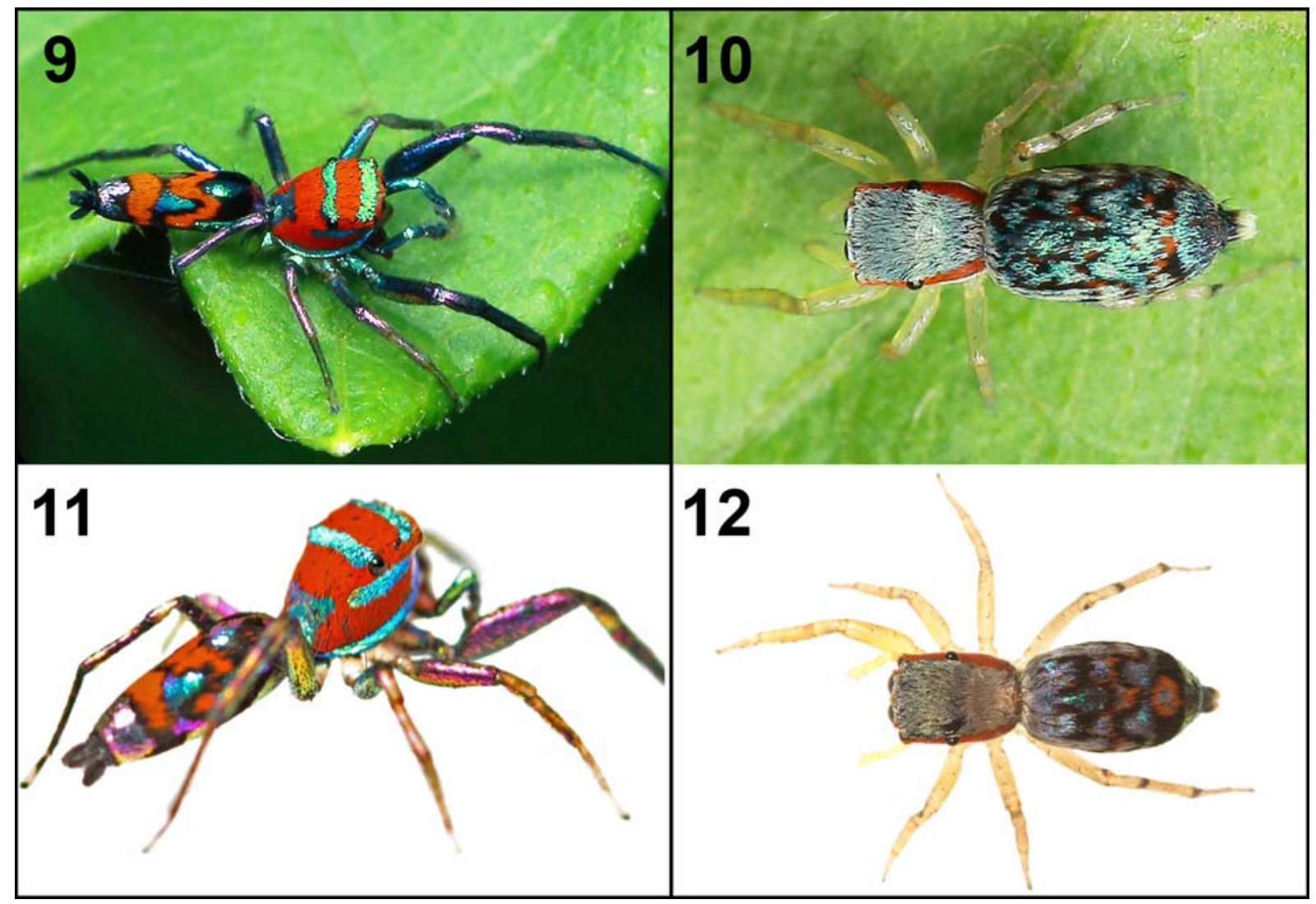

Figs 9-12. General appearance of male $(9,11)$ and female $(10,12)$ of Chrysilla volupe (Karsch, 1879): 9-10 - specimens from Wayanad, Kerala; 11-12 - specimens from NCBS campus, Bengaluru. Photo credits: 9-10 - K.S. Nafin; 11-12 - Rajesh V. Sanap.

Рис. 9-12. Общий вид самца $(9,11)$ и самки $(10,12)$ Chrysilla volupe (Karsch, 1879): 9-10 - экземпляры из Вайананд, Керала; 11-12 - экземпляры с территории университета NCBS, Бенгалуру. Фотографии: 9-10 - К.С. Нафин; 11-12 - Раджеш В. Санап.

iridescent scales reflecting bluish tinge; cymbium apically yellow; embolus needle-like, arising at 12 o'clock position; proximal protrusion of palpal tegulum saclike; tegular bump present retrolaterally; RTA long with broad base narrowing toward the tip, curving ventrad (Fig 17-21).

Female (NCBS-AU141). Total length: 2.61; carapace: 1.10 long, 0.86 wide; abdomen: 1.51 long, 0.88 wide. Eye measurements: AME 0.26, ALE 0.15, PME 0.17, PLE 0.30, AER 0.82, PER 0.88, EFL 0.56; AMEAME 0.01, AME-ALE 0.01, ALE-PME 0.20, PMEPME 0.72, PME-PLE 0.12, PLE-PLE 0.69. Clypeus height 0.04. Leg measurements: I 2.14 (0.66, 0.41, $0.48,0.36,0.23)$; II $1.82(0.60,0.32,0.37,0.33,0.20)$; III $1.99(0.63,0.31,0.37,0.45,0.23)$; IV $2.73(0.85$, $0.34,0.57,0.67,0.30)$. Leg formula: 4132 .

Colour pattern as in the male, but differs as follows: carapace covered with greyish scales dorsally and devoid of bluish stripes laterally; carapace rim outlined by white scales (Figs 2, 4); clypeus uniformly covered with reddish orange scales. Anterior eyes with grey eyebrows (Figs 4, 14). All legs yellowish; leg IV with dark annulations near the joints of femur, patella and tibia (Figs 2, 4, 6). Epigyne with the closely positioned copulatory openings, facing laterally, situated under a wide anterior flap; posterior margin sclerotized, wide W-shaped; copulatory ducts long, anterior half of the copulatory ducts parallel; spermathecae spherical, contiguous (Figs 22-25).

DISTRIBUTION. Sri Lanka; Bhutan; India (Tamil Nadu, Kerala, Karnataka, Maharashtra, Gujarat, Uttarakhand) (Map). Caleb \& Mathai [2014] erroneously mentioned Burma instead of Bhutan in the species' distribution.

LIFE HISTORY. Both sexes of $C$. volupe were collected during an arachnology survey in Aarey Milk Colony, Mumbai, carried out in June 2017. These individuals were collected from a lemon tree in a forest patch growing near the human settlement. All the collected females were separately housed in small containers. Two gravid females laid 4-5 eggs, one on the 10 th of July (egg sac 1) and the other on the 12th of July (egg sac 2), respectively. Both egg sacs were separately incubated in small plastic containers at room temperature $\left(\sim 25^{\circ} \mathrm{C}\right)$ to observe the development of eggs (Fig. 26). Eggs in the sac 2 died the next day. Thus, the following account is based on the observations obtained from the egg sac 1 (Figs 26-37).

Four more or less same sized yellow eggs were laid (Fig. 26). No development or changes were observed 

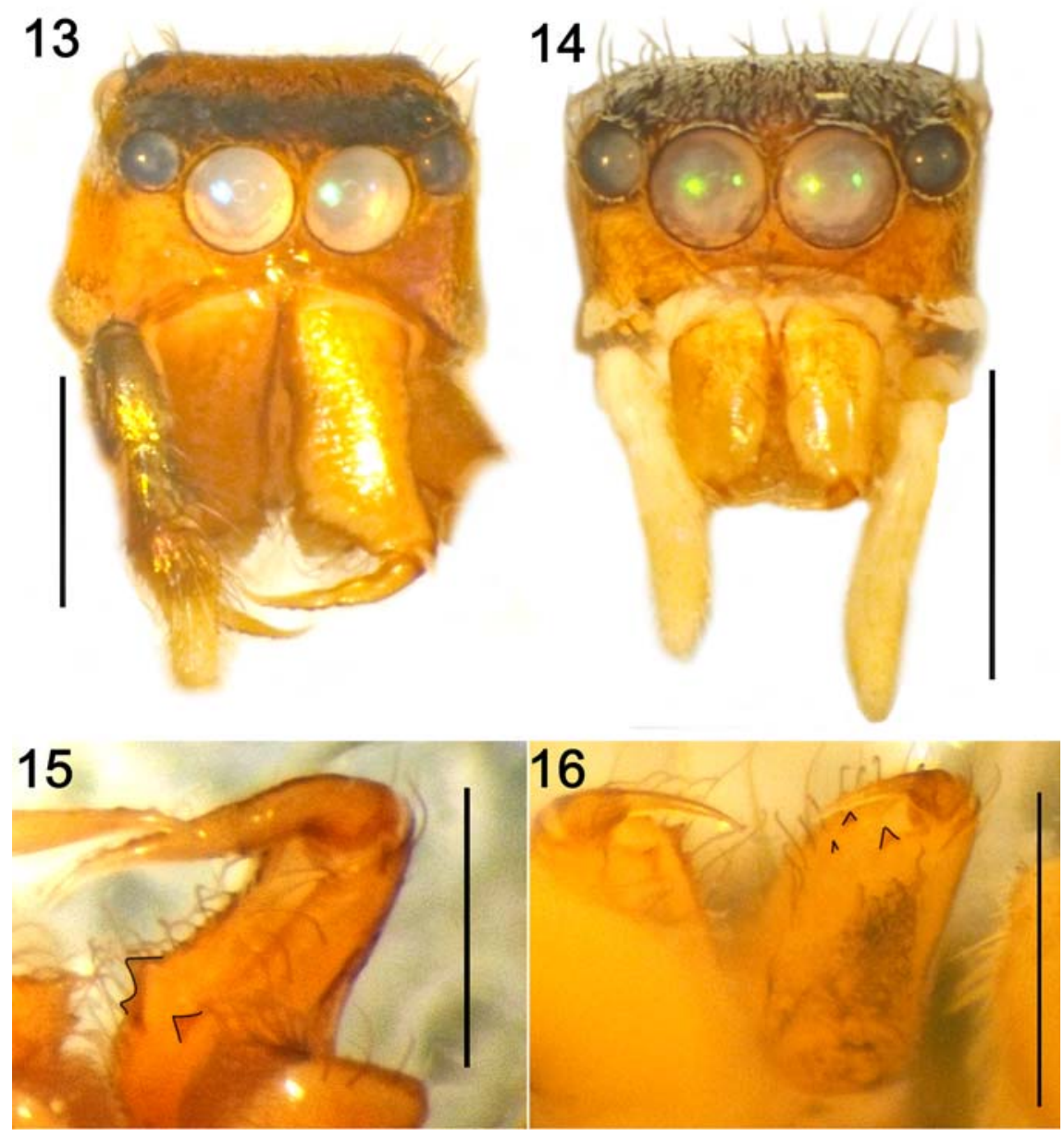

Figs 13-16. Somatic characters of Chrysilla volupe (Karsch, 1879): 13 - front view, male; 14 - ditto, female; 15 — chelicera, male; 16 - ditto, female. Scale bars: $1 \mathrm{~mm}(13-14) ; 0.5 \mathrm{~mm}(15-16)$.

Рис. 13-16. Соматические признаки Chrysilla volupe (Karsch, 1879): 13 - самец, вид спереди; 14 - самка, вид спереди; 15 хелицера самца; 16 - тоже самки. Масштаб: 1 мм (13-14); 0,5 мм (15-16).

except for a slightly faded colour on the eggs until the 14 th of July (Fig. 28). In about six days, on the 16th of July, a large light yellow spot appeared on the eggs, which covered approximately half of the egg surface (Fig. 29). On the following day, the light yellow spot further began developing into body parts; legs and abdomen were visible. The eggs appeared to have hatched; the nymphs could be distinctly identified, but they remained without movement for about three days. By the end of the third day, all body parts became distinct (Fig. 30). On the 20th of July nymphs were completely out of their cases. The abdomen appeared dark yellow and the carapace was whitish, with black patches visible near the eyes (Fig. 31).

On the following two days, the nymphs were independently moving; their colour remained unchanged except for visible dark black patches on the eyes which further darkened (Fig. 32) and dark border outlining the carapace (Fig. 33). On the 23rd of July, the black patches near eyes became darker and brown patches appeared on the abdomen (Fig. 34); the 25th of July
(Fig. 35); the 27th of July (Fig. 36). The nymphs underwent their first moult on the 28th of July. Black stripes appeared on the legs, and setae developed all over the body. A reddish sheen was observed on the abdomen, and the carapace shape became distinct and more compact (Fig. 37). By the end of the first instar only three out of five nymphs survived. The remaining three nymphs were later released into the wild due maintenance difficulties in the laboratory conditions.

\section{Chrysilla guineensis (Wesołowska et Wiśniewski, 2013), comb.n.}

Phintella guineensis Wesołowska et Wiśniewski, 2013: 247, figs 1-9 (Description of $\sigma^{7}+$ ). The type is not re-examined.

REMARKS. Phintella guineensis was originally described from West Africa based on the holotype male and three paratype females. The species is strikingly similar to Chrysilla species, sharing the following characters: body morphology with elongated abdomen and colour pattern (cf. figs 1, 2, 7 in Wesołowska 


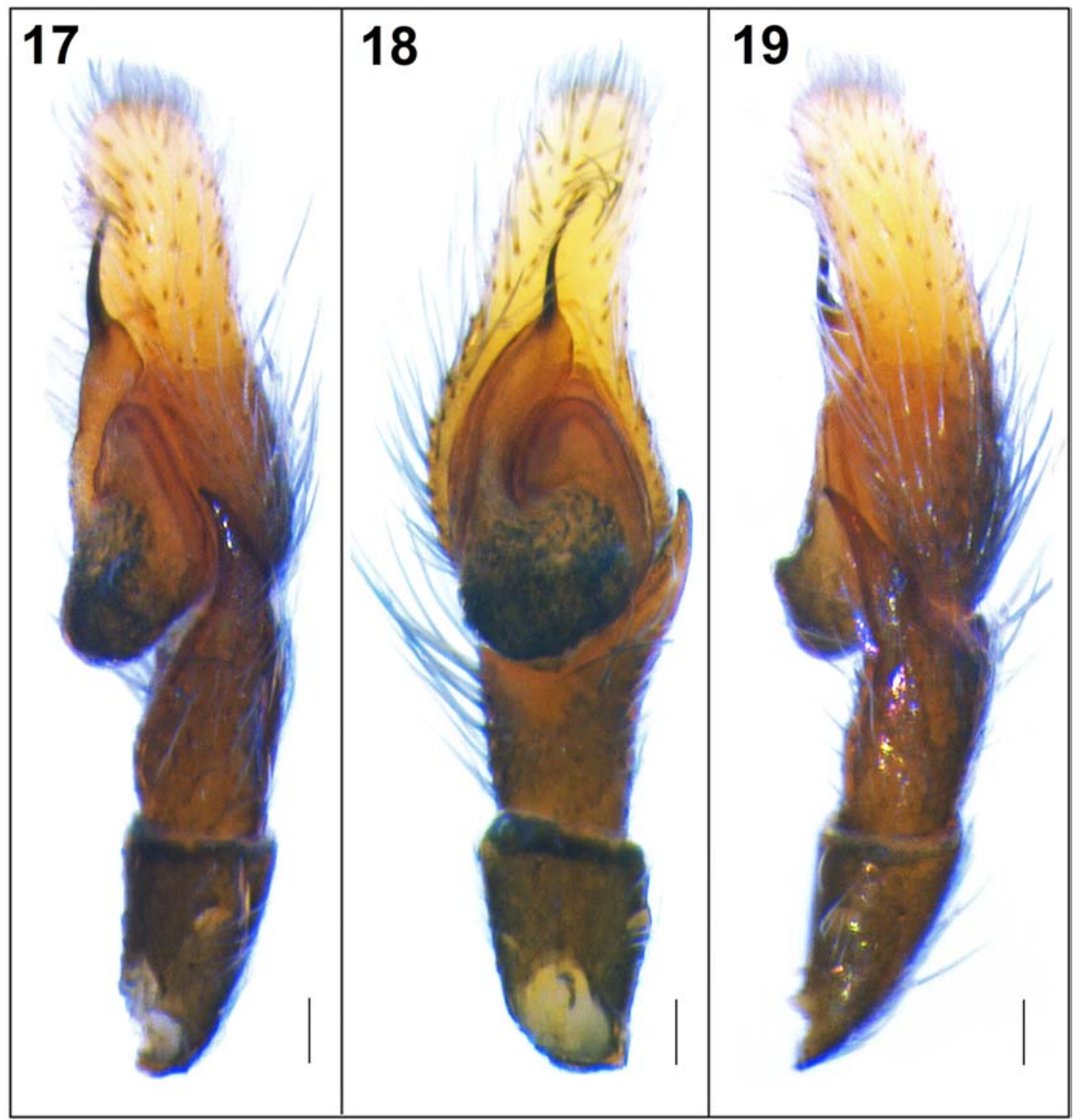

Figs 17-19. Left male palp of Chrysilla volupe (Karsch, 1879): 17 - ventro-retrolateral view; 18 - ventral view; 19 - retrolateral view. Scale bars: $0.1 \mathrm{~mm}(17-19)$.

Рис. 17-19. Левая пальпа самца Chrysilla volupe (Karsch, 1879): 17 — вид снизу-ретролатерально; 18 — вид снизу; 19 — вид ретролатерально. Масштаб: 0,1 мм (17-19).

\& Wiśniewski [2013] with Figs 7-10); the male palp with a narrow and elongated cymbium; pointed RTA; triangular bulb with posterior protrusion and the relatively long embolus (cf. figs 3-6 in Wesołowska \& Wiśniewski [2013] with figs 34-37 in Prószyński \& Deeleman-Reinhold [2010] and Figs 17-21); the epigyne with copulatory openings hidden under the large, wide, anterior pocket; vulva with the elongated insemination ducts and spherical spermathecae (cf. fig. 9 in Wesołowska \& Wiśniewski [2013] with Figs 22-25). The close similarity of the copulatory organs in this species with the generotype and related species of the genus Chrysilla leave no doubts that the species name P. guineensis is to be transferred to Chrysilla.

Карта. Распространение Chrysilla volupe (Karsch, 1879), в том числе и по фото-указаниям. 1 - оз. Париедж; 2 - Тане; 3 молочная колония Арей; 4 - Сангли (фото-указание, Амол Джадхав); 5 - Хайдерабад (видео-указание [Rаm, 2008]); 6 территория университета NCBS, Бангалур; 7 - Вайанад; 8 - территория МСC, Тамбарам; 9 - Тирумуллаивоял; 10 - город Соленое Озеро, Колката (фото-указание, Анубхав Агарвал [IBP, 2018]); 11 - Фуентшолинь, Бутан; 12 - биосферный заповедник Нанда Деви (фото-указание, Шазия Квазин [Prószyński, 2016]); ? - типовой локалитет в Шри-Ланке, точно местоположение не известно. 
Figs 20-21. Left male palp of Chrysilla volupe (Karsch, 1879): 20 - ventral view; 21 retrolateral view. Abbreviations: E - embolus; RTA — retrolateral tibial apophysis; SD — sperm duct. Scale bars: $0.1 \mathrm{~mm}(20)$.

Рис. 20-21. Левая пальпа самца Chrysilla volupe (Karsch, 1879): 20 - вид снизу; 21 вид ретролатерально. Сокращения: Е - эмболюс; RTA - ретролатеральный тибиальный отросток; SD - семенной каналец. Масштаб: 0,1 мм (20).
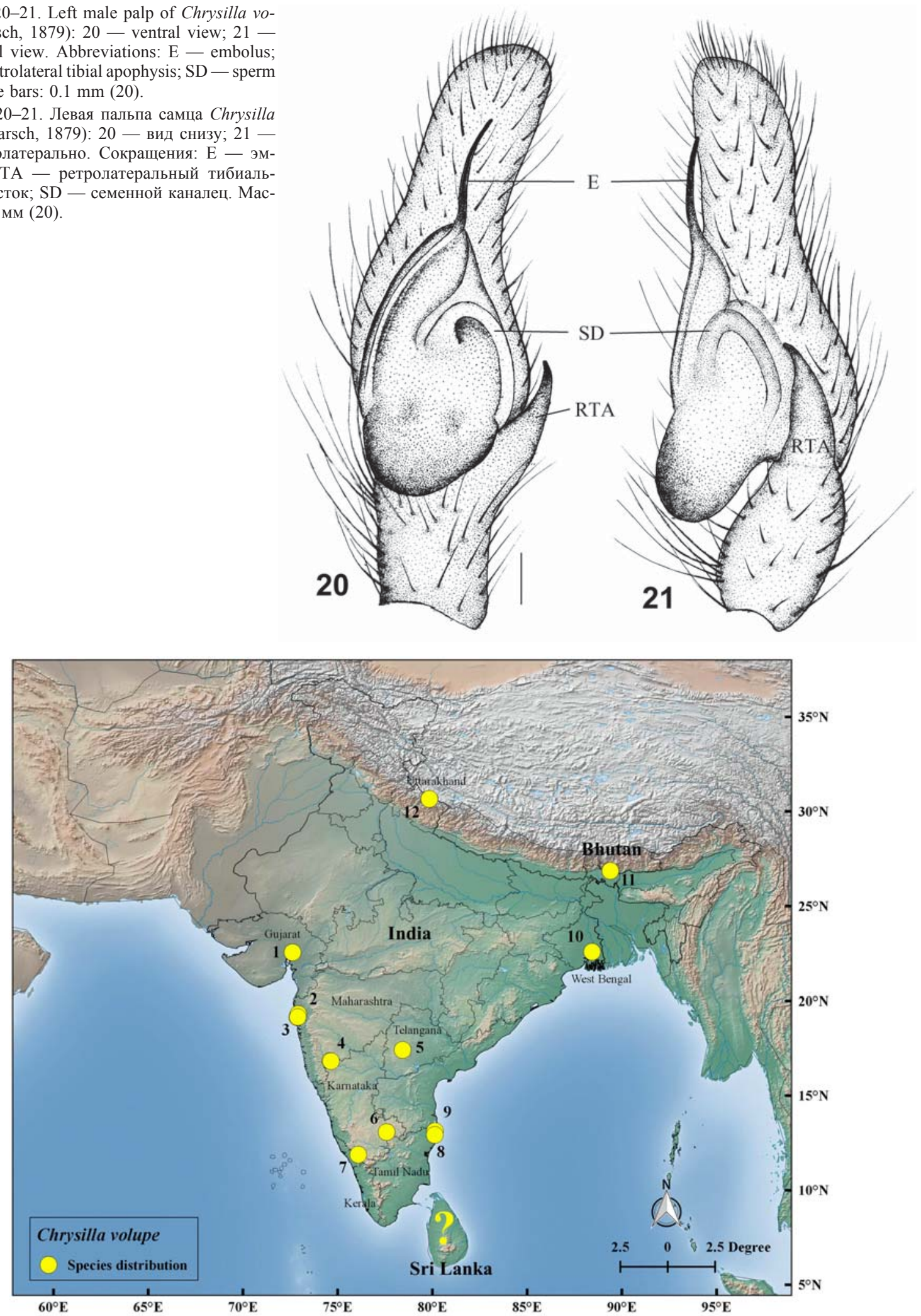

Map. Distribution of Chrysilla volupe (Karsch, 1879), including photographic records. 1 - Pariyej lake; 2 - Thane; 3 - Aarey milk colony; 4 - Sangli (photographic record by Amol Jadhav); 5 - Hyderabad (videographic record by Ram [2008]); 6 - NCBS campus, Bangalore; 7 - Wayanad; 8 - MCC campus, Tambaram; 9 - Thirumullaivoyal; 10 - Salt Lake city, Kolkata (photographic record by Anubhav Agarwal [IBP, 2018]); 11 - Phuentsholing, Bhutan; 12 - Nanda Devi Biosphere reserve (photographic record by Shazia Quasin [Prószyński, 2016]); ? - Type locality in Sri Lanka, the exact location is unknown. 

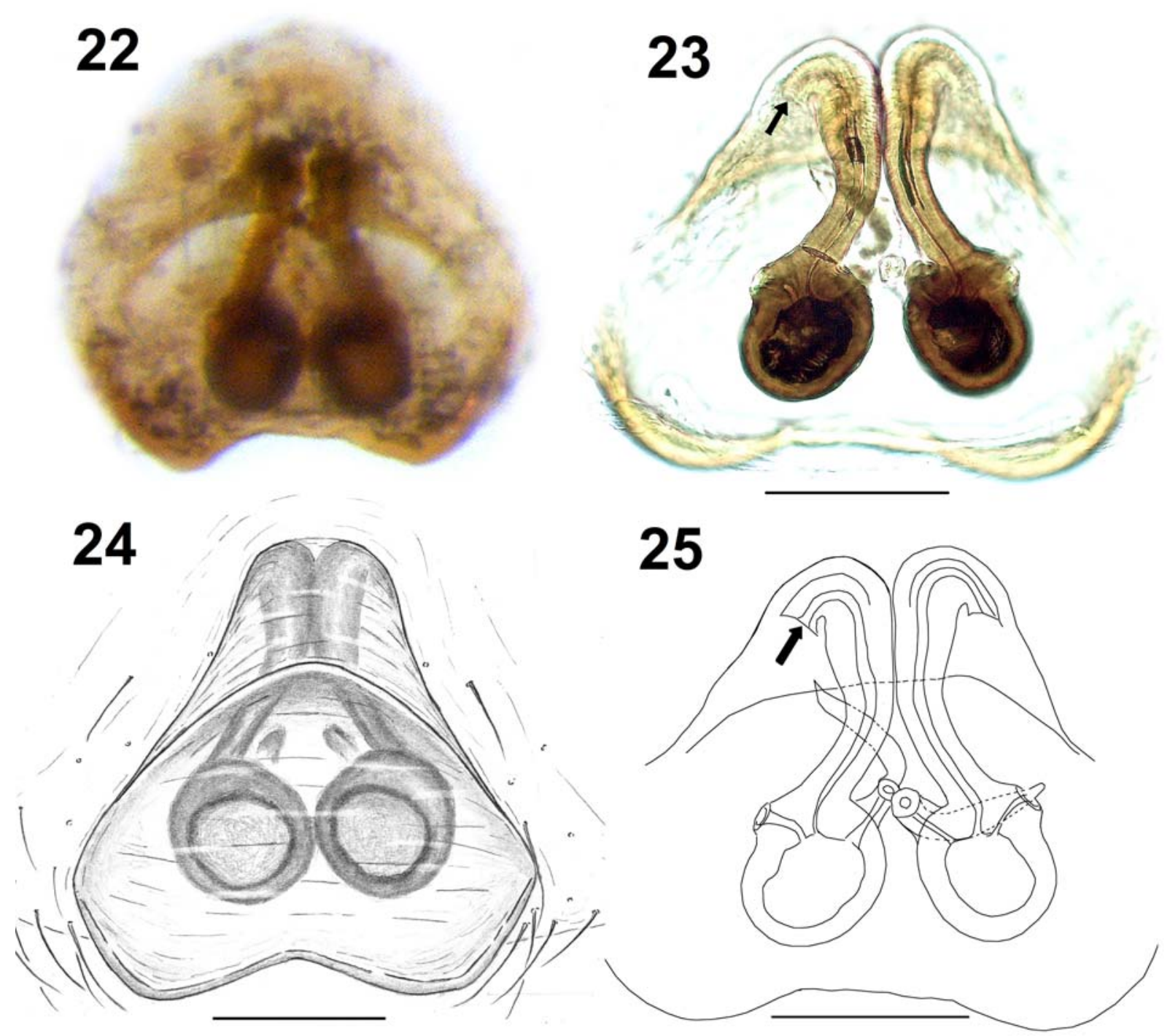

Figs 22-25. Female copulatory organs of Chrysilla volupe (Karsch, 1879): 22 - epigyne, ventral view; 23 - vulva, dorsal view; 24 epigyne, ventral view; 25 - vulva, dorsal view. Scale bars: $0.1 \mathrm{~mm}(22-25)$.

Рис. 22-25. Копулятивные органы самки Chrysilla volupe (Karsch, 1879): 22 - эпигина, вид снизу; 23 - вульва, вид сверху; 24 - эпигина, вид снизу; 25 - вульва, вид сверху. Масштаб: 0,1 мм (22-25).

ACKNOWLEDGEMENTS. We wish to thank Yuwraj Gurjar for contributing images. RS and JC thank Dr Krushnamegh Kunte, National Centre for Biological Sciences (NCBS) in Bengaluru, for allowing us to use the stereomicroscope facility and to deposit the specimens. We are grateful to Ranjeet Jadhav, Imran Udat, Kunal Chudhari, Satish Lot, Kishor Patre, Ravi Patre, Sidhesh Waghamare, Paresh Churi, Yatin Gholap, Prabhu Swami, Job Daniel and Brainard for their logistic support and assistance during field work. Thanks go to Mr. Amol Jadhav for sharing his images of the species. Thanks go to Ms. Anuradha Joglekar for editing the manuscript and providing the map. JC wants to thank Dr Kailash Chandra, the Director, Zoological
Survey of India, Kolkata for giving access to the facilities and for general support. JC also acknowledges the American Arachnological Society for the Arachnology grant from the Herbert Levi fund (HLMFAR). PS, KN and AS are grateful to Dr Mathew Paul Ukken, Principal in-Charge, Christ College, Irinjalakuda, Kerala, for giving access to the necessary facilities for this research. We are thankful to the Principal Chief Conservator of Forests, Kerala, for the collection permit and also to the Wildlife Warden and the field staff of the Wayanad Wildlife Sanctuary, Kerala for the hospitality and field support. PS, KN and AS also acknowledge Science \& Engineering Research Board (SERB) DST, New Delhi, for providing financial support under the 


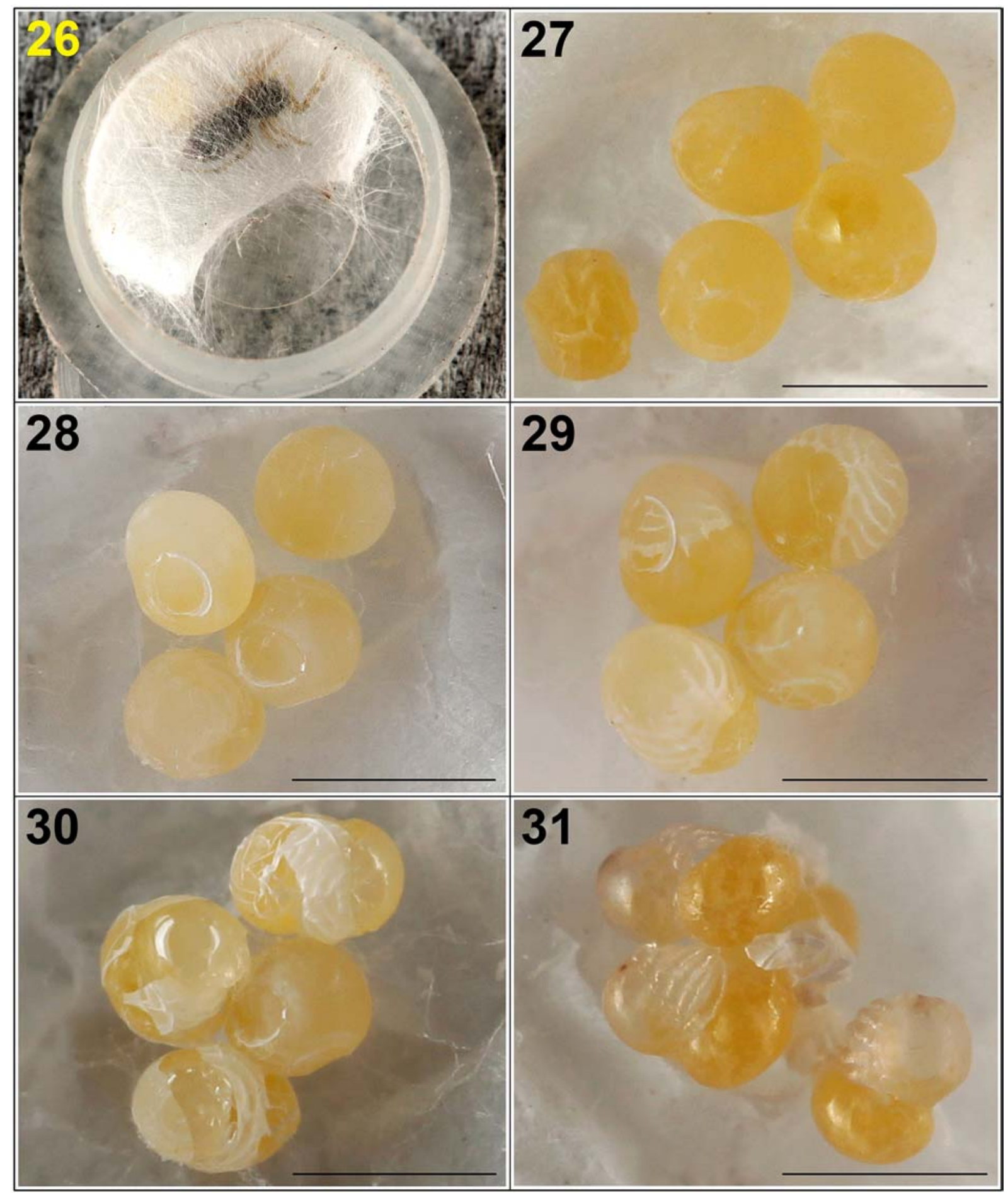

Figs 26-31. Developmental stages of the eggs of Chrysilla volupe (Karsch, 1879): 26 - female inside the retreat, laid four eggs on 10th of July $2017 ; 27$ — eggs on day 1 (July 10th); 28 — ditto on day 5 (July 14th); 29 — ditto on day 7 (July 16th); 30 — ditto on day 8 (July 17th); 31 - nymphs on day 11 (July 20th). Scale bars: 1 mm. Photo credits: Rajesh V. Sanap.

Рис. 26-31. Стадии развития яиц Chrysilla volupe (Karsch, 1879): 26 - самка внутри убежища, отложила четыре яйца 10 июля 2017 г.; 27 - яйца, день 1 (10 июля); 28 - яйца, день 5 (14 июля); 29 - яйца, день 7 (16 июля); 30 - яйца, день 8 (17 июля); 31 нимфы, день 11 (20 июля). Масштаб: 1 мм. Фотографии: Раджеш В. Санап. 


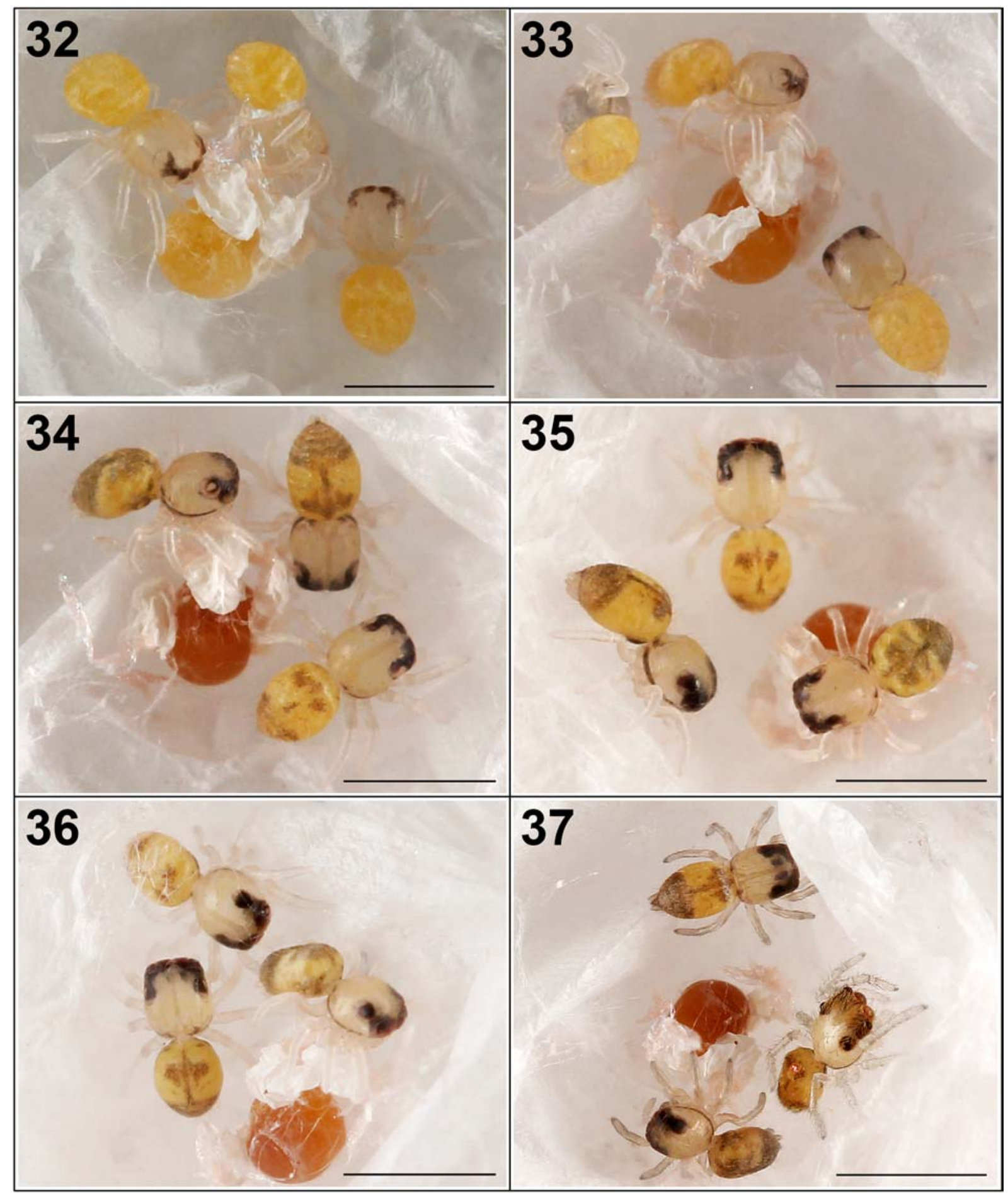

Figs 32-37. Developmental stages of the nymphs of Chrysilla volupe (Karsch, 1879): 32 - day 12 (21st of July, 2017); 33 - day 13 (July 22nd); 34 - day 14 (July 23rd); 35 - day 16 (July 25th); 36 - day 18 (July 27th); 37 - nymphs after the first moult, day 19 (July 28th). Scale bars: $1 \mathrm{~mm}$. Photo credits: Rajesh V. Sanap.

Рис. 32-37. Стадии развития нимф Chrysilla volupe (Karsch, 1879): 32 - день 12 (21 июля 2017 г.); 33 — день 13 (22 июля); 34 день 14 (23 июля); 35 - день 16 (25 июля); 36 - день 18 (27 июля); 37 - нимфы после первой линьки, день 19 (28 июля). Масштаб: 1 мм. Фотографии: Раджеш В. Санап. 
Young Scientist Research project: No. SB/YS/LS-86/ 2013. Finally, we wish to thank Dr Dmitri Logunov (Manchester, UK) for his valuable suggestions and editorial help that greatly improved the manuscript.

\section{References}

Caleb J.T.D. 2016. New data on the jumping spiders (Araneae: Salticidae) from India // Arthropoda Selecta. Vol. 25. No.3. P.271-277.

Caleb J.T.D., Mathai M.T. 2014. Description of some interesting jumping spiders (Araneae: Salticidae) from South India // Journal of Entomology and Zoology Studies. Vol.2. No.5. P. 6371

IBP 2018. India Biodiversity Portal. Biodiversity India; online at: http://indiabiodiversity.org/observation/show/1740110?pos= (accessed on 10th January 2018).

Karsch F. 1879. Arachnologische Beiträge // Zeitschrift für die Gesammten Naturwissenschaften. Vol.52. P.534-562.

Prószyński J. 1985. On Siler, Silerella, Cyllobelus and Natta (Araneae, Salticidae) // Annales zoologici. Warszawa. T.39. No.2. P.69-85.

Prószyński J. 2016. Salticidae (Araneae) of the world, Chapter II. Available at http://peckhamia.com/salticidae/salticidae.php. (accessed on 10th January 2018).
Prószyński J., Deeleman-Reinhold C.L. 2010. Description of some Salticidae (Araneae) from the Malay Archipelago. I. Salticidae of the Lesser Sunda Islands, with comments on related species // Arthropoda Selecta. Vol.19. No.3. P.153-188.

Ram M.S. 2008. Iridescent spider. Available online at https:// www.youtube.com/watch? $v=$ nu1Yxx61IxQ (accessed on 10th January 2018).

Thorell T. 1887. Viaggio di L. Fea in Birmania e regioni vicine. II. Primo saggio sui ragni birmani // Annali del Museo Civico di Storia Naturale di Genova. Vol.25. P.5-417.

Wang L.Y., Zhang Z.S. 2012. A new species of Chrysilla Thorell, 1887 from China (Araneae: Salticidae) // Zootaxa. Vol.3243. P.65-68.

Wesołowska W., Wiśniewski K. 2013. New species of Phintella from West Africa (Araneae: Salticidae: Heliophaninae) // Genus. Vol.24. No.2. P.247-250.

WSC 2018. World Spider Catalog. Natural History Museum Bern; online at: http://wsc.nmbe.ch, version 18.5 (accessed on 4th January 2018).

Żabka M. 1988. Salticidae (Araneae) of Oriental, Australian and Pacific regions, III // Annales Zoologici, Warszawa. Vol.41. P.421-479.

Responsible editor D.V. Logunov 